\title{
Reading 1 Corinthians 7:10-11 in the context of intimate partner violence in Nigeria
}

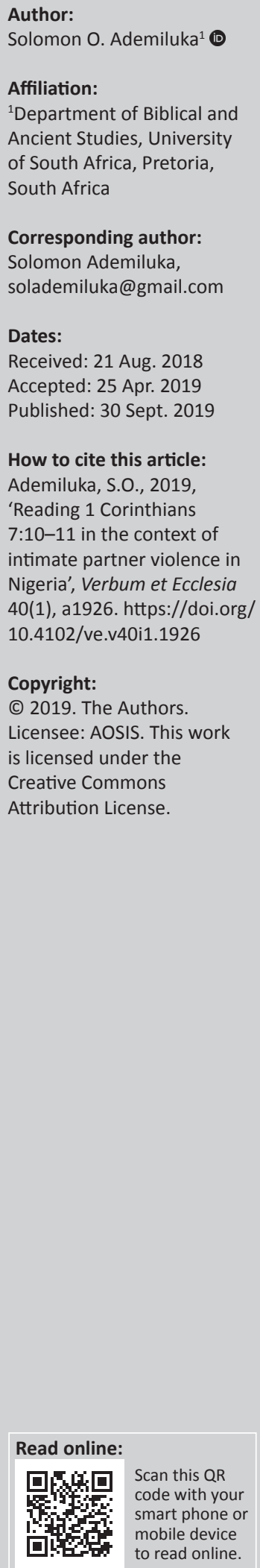

\begin{abstract}
In Nigeria, most of the mainline churches forbid divorce and remarriage, and one of the passages most popularly quoted in support of this doctrine is 1 Corinthians 7:10-11. The traditional interpretation teaches that marriage is 'for better, for worse' and should be between one man and one woman for life. In view of the fact that this mode of interpretation is capable of enhancing the already high rate of domestic violence, this work examines the text in the context of intimate partner violence (IPV) in Nigeria. Applying the analytical and exegetical methods, the essay investigates the possible correlation between the doctrine of no divorce and IPV. The research found that when understood against its specific context, 1 Corinthians 7:10-11 permits divorce and remarriage on grounds of adultery, and allows a deserted Christian spouse to remarry. It can also be deduced from the chapter that when IPV poses threat to life, divorce may be the appropriate response, and the affected spouses are free to remarry. In this way, a proper understanding of the passage can go a long way to reducing the rate of domestic violence in Nigeria. It is noteworthy, however, that the overall intent of the text is to protect marriage as a permanent institution, hence even when divorce has taken place, the church and concerned couples should still seek reconciliation.
\end{abstract}

Intradisciplinary and/or interdisciplinary implications: The work employs the analytical approach for the investigation of the correlation between the doctrine of no divorce and IPV, and the exegetical method to the study of 1 Corinthians 7:10-11 and other related texts.

Keywords: divorce; remarriage; Christians; Nigeria; IPV.

\section{Introduction}

Simply defined, intimate partner violence (IPV) refers to any act which a person carries out to hurt another with whom he or she is in some form of emotional relationship, such as between husband and wife. Intimate partner violence is a social problem that is currently prevalent all over the world. In Nigeria, as in most parts of Africa, women are often at the receiving end of IPV. While there are many factors that engender IPV, this article endeavours to establish a possible correlation between violence against women and the prohibition of divorce and remarriage in some churches in Nigeria as based on 1 Corinthians 7:10-11. As Nigeria is a large country, the study of a Christian doctrine will be more comprehensive if it focuses on a specific region; however, in this country, doctrinal differences are manifest more along denominational than regional lines. In most African-initiated churches, divorce and remarriage are no issues as they are welcome practices; hence, this work focuses on the doctrine of no divorce as officially taught in the mission-oriented churches. In these denominations, the doctrine on marriage and divorce largely follows the traditional interpretation of 1 Corinthians 7. Apparently relying on verses 10-11 and 39, this interpretation postulates that marriage should be between one man and one woman for life; it is also 'for better, for worse', that is, on no account should one divorce.

The present author views this mode of interpretation as capable of enhancing the already increasing rate of IPV in Nigeria, as abused spouses are often urged to remain in even the most life-threatening marriages. The aim of this article, therefore, is to investigate the possible correlation between the prohibition of divorce based on 1 Corinthians 7:10-11 and IPV in Nigeria; it also examines the text against its social context with a view to ascertaining its original intent in relation to divorce and remarriage. Thus, the significance of the research resides in the establishment of a nexus between the doctrine of no divorce and IPV; the significance which applies specifically to those Nigerian churches that hold tenaciously to this teaching. The work employs the analytical approach for the investigation of the correlation between the doctrine of no divorce and IPV. In order to do this analysis, material is gathered on divorce prohibition as taught by the churches concerned as well as the increasing rates of divorce and IPV in Nigeria. 
The article applies the exegetical method to the study of 1 Corinthians 7:10-11 and other related texts, examining these passages against their original socio-religious backgrounds.

\section{Ethical considerations}

This article followed all ethical standards for research without direct contact with human or animal subjects.

\section{The Christian doctrine on marriage and divorce in Nigeria}

In Nigeria, apart from some African-initiated churches which permit divorce and remarriage (Kunhiyop 2008:250), the Christian doctrine on marriage and divorce adheres to the literal interpretation of the New Testament passages bordering on the subject, namely the sayings of Jesus in the synoptic gospels, and especially 1 Corinthians 7. Most Christians involve the church in their marriage processes, particularly the solemnisation, the occasion during which couples are admonished to adhere to the Christian tenets on marriage. 'One of these tenets is the dogma of "for better, for worse", which means the couple must accept the consequences of their decision whatever the outcome, good or bad' (Anenga 2017). This dogma simply encapsulates the prohibition of divorce as it obtains in many denominations. Most denominations in Nigeria officially adhere to this teaching, in which couples are expected to 'endure whatever challenge they are facing ... even at the risk of their lives' (Canada: Immigration and Refugee Board of Canada 2012). The Constitution of the Diocesan Synod of the Diocese of Lagos West (Anglican Communion) emphasises that (Adesanya 2009):

The Church believes that marriage, by divine institution, is a life-long and exclusive union and partnership between one man and one woman. Indeed the Church's rites at marriage ceremonies state as much. It is a union that endures till 'death do us part'. (p. 3)

Most denominations administer this oath to their members during the wedding solemnisation, in which both bride and groom promise to keep 'in sickness or in health, in riches or in poverty, for better, for worse and forsaking all others ... as long as you both shall live' (The Redeemed Christian Church of God 2010:6; cf. United Missionary Church of Africa 2013:8). As we shall see later, the notion that couples are bound by their marriage oath until either of them dies derives from a traditional interpretation of 1 Corinthians 7:39.

The definiteness of the prohibition of divorce can be illustrated with the position of the Roman Catholic Church. In obedience to Jesus' teaching (Moore 2017):

The Church believes that marriage is a lifelong bond (cf. Mt 19:1-10). ...The Catholic Church does not permit divorce for valid sacramental marriages. In fact a valid sacramental marriage is impossible to dissolve thereby making divorce not possible if the marriage was sacramental. In marriage the two become one flesh in a union joined by God (Mk 10:8-9). ... So for a marriage that meets the requirements of being a sacrament, divorce in the Catholic Church is not possible. (n. p.)
However, the Catholic Church practices what is called marriage annulment, which can easily be confused with divorce, even though it maintains that the two are different from each other. While divorce is a civil law decree from the state, an annulment occurs when (Moore 2017):

A Church tribunal declares that a marriage thought to be valid ... actually fell short of ... the essential elements required for a binding union ... [Hence] an annulment basically says that the Sacrament of Matrimony never took place to begin with ... [Thus whereas] a civil divorce basically says that what was once a marriage is no longer a marriage ... a Church annulment declares that the Sacrament of Matrimony didn't occur from day one. (n. p.)

It is important to note, however, that in spite of the stern prohibition, divorce is still rampant among Christian couples in Nigeria; and this is widely acknowledged by the leadership of the Church itself. In this regard, Pastor Adebola Ogunleye of the Foursquare Gospel Church, Lagos, described as alarming the rate of divorce among Christians, urging members to address the 'root causes of marriage problems leading to divorce' ('Cleric laments ...' 2018). Similarly, Bishop Michael Frencher of the African Methodist Episcopal Zion Church, Port Harcourt, Rivers State, has decried 'the rate at which young Christian couples divorce in Nigeria' (Christian Media in Nigeria 2015). The church leaders are not only worried about the problem of divorce among Christians, they have also suggested some solutions for it. According to the Bishop, to minimise divorce among Christians in Nigeria, there is need to inculcate Christian virtues on families' (Christian Media in Nigeria 2015).They also believe that the various denominations can check the alarming rate of divorce 'through regular counseling of couples, especially after marriage' (Johnson 2018). Marriage counselling should not be limited to the period of courtship, but should continue after the wedding; in this way, divorce among Christian couples will be considerably reduced.

While the factors responsible for divorce are varied, in Nigeria, most cases of divorce among Christians are preceded by IPV. Hence, in the following sections, we shall examine the prevalence of this menace in Nigeria, and how the attitude of the church towards it is influenced by its prohibition of divorce.

\section{Intimate partner violence in Nigeria}

As defined by the Centers for Disease Control and Prevention (CDC):

Intimate Partner Violence encompasses acts of stalking, psychological aggression, physical violence or sexual violence behaviors and tactics through which an intimate partner seeks to establish and maintain power over another. (cited by Hasstedt \& Rowan 2016)

As further explained by the CDC, an intimate partner is a person with whom one has or had a close personal relationship that is characterised by 'emotional connectedness, regular contact, ongoing physical contact and/or sexual 
behavior, identity as a couple, familiarity and knowledge about each other's lives' (CDC 2014). Sexual violence is a prominent form of IPV, and the CDC defines it as:

An attempted or committed sexual act perpetrated against a person who has not freely given consent or is unable to refuse ... [which] includes rape [and] other forced or unwanted sexual contacts. (CDC 2014)

The term 'domestic violence' is often used synonymously with 'intimate partner violence'. Thus, according to the United States (US) Department of Justice:

Domestic violence can be defined as a pattern of abusive behaviour in any relationship that is used by one partner to gain or maintain power and control over the other intimate partner. (cited by Essien 2017).

Putting it simply, Kunhiyop (2008:244) states that ' $[d]$ omestic violence involves the abuse of power in intimate relationships within a household'. Some people equate IPV with women abuse, in that (although women perpetrators of IPV are not lacking) most often women are the victims (Kirk-Dugan 2012:259). As Kunhiyop (2008:244) puts it, women are usually the victims of domestic violence as it is rarely perpetrated by women against men.

The prevalence of IPV is attested all over the world. Folayan et al. (2014) affirm that worldwide women frequently 'face tremendous sexual violence'. This fact is buttressed by a 2014 UNICEF report which confirms that 'around 120 million girls worldwide ... have experienced forced intercourse or other forced sexual acts at some point in their lives' (BabajideAlabi 2017). In Africa, IPV is prevalent in the form of women abuse. Many believe that the African patriarchal culture makes the African woman vulnerable to domestic violence in numerous ways. According to Okorie (2003:258), the African woman is better 'described as a "woe-man" [as] she is always at the receiving ends of cultures and traditions which suppress, oppress, exploit, and abuse her'. Baloyi (2010a:2) identifies several ways by which the African patriarchal culture leaves room for violence against women. According to him, there are African idioms which emphasise and encourage domination of women, and women are often beaten and sexually abused in Africa (cf. Partab 2011:96). Abogunrin (2003:2) explains that ' $[w]$ omen suffer stereotyped expectations of subordination as sex objects with no mind or will of their own'. In another article, with a focus on South Africa, Baloyi (2010b) portrays African culture as one in which women are viewed as sexual objects, and this is reflected in both print and electronic media, indicating that women abuse 'is one of the fastest growing misdeeds in South Africa'. Violence against women is similarly rampant in Nigeria. Some 'reports have shown that $4 \%-6 \%$ of all adolescent girls in southwestern Nigeria experience rape' (Folayan et al. 2014). One study reveals '181 rape cases within six months in Lagos State alone' (Baffour 2014). In Nigeria, there is no age limit to rape; 'children, babies, adolescents, matured adults, mothers, grandmothers, and women of over 70 years are raped' (Baffour 2014).
However, more important for the purpose of this research are the various forms of physical violence other than the sexual. In Nigeria, as in many parts of Africa, corporal punishment for wives 'is widely sanctioned as a form of discipline' (Ose 2009). As Baloyi (2013:1) rightly observes, among some African people, 'the practice of wife beating has become an accepted way of keeping wives under control'. Hence, when men beat their wives they 'believe they are instilling discipline in them ... [as women] are regarded as children who can be prone to indiscipline if not disciplined' (Agbonkhese \& Onuoha 2017). Unfortunately, in some parts of Nigeria, as in other parts of Africa, even the majority of women themselves 'believe that physical abuse is most times justified' (Agene 2017), as they have been made to believe that it is an inevitable part of African tradition (cf. Baloyi 2013:1; Okenwaet al. 2009).

This might explain the widespread nature of domestic violence in Nigeria, as in other parts of Africa. It is reported that in Nigeria, $25 \%$ of women 'go through ordeal of domestic violence' (Hart 2016). In the enumeration of Antai (2011), in Nigeria, acts of physical violence against women include:

i) pushing, shaking or throwing something at her; ii) slapping her or twisting her arm; iii) punching or hitting her with something harmful; iv) kicking or dragging her; $v$ ) strangling or burning her; vi) threatening her with a weapon (e.g., gun or knife); and vii) attacking her with a weapon. (Online)

Igbelina-Igbokwe (2013) includes other acts like 'wife battery, acid bath ... harmful traditional practices (e.g., female genital mutilation), widowhood rites/disinheritance, deprivation of material and economic resources [and] ... restriction of mobility'. Delano (1998) affirms that these forms of abuse are widespread across sub-Saharan Africa. According to the author, surveys conducted in this region reveal that in Nigeria ' 81 percent of married women report being verbally or physically abused by their husbands. Forty-six percent report being abused in the presence of their children' (Delano 2017:n.p.).

Before we examine the attitude of the church in Nigeria to domestic violence among its members, it is important to point out that the church itself is not absolved from the problem. This is because women abuse is often reported among church leaders and pastors, which invariably influences the attitude of the church to IPV. Such reports indicate that 'some men on the altar are demons disguised as angels' in view of the fact that some church elders and pastors have been found guilty of rape, wife battery and other criminal acts against women (Woman.NG 2017). Stories abound of youth pastors raping underage and teenage girls who are members of their congregations (Woman.NG 2017).

There are reports of wife beating even among pastors. For example, it is reported that a pastor in Port Harcourt, Rivers State, had the habit of beating his wife, although 'the elders of the church knew about it [but] everyone [was] afraid to touch God's anointed' (Fowowe 2015). Egbujo (2015) tells the story of a Lagos-based 'urbane vicar (Anglican) whose sense of piety tolerated chasing his wife around the church 
premises in full glare of congregants to effect priestly moral chastisement'. In 2017, at Awka in Anambra State, a pastor of a charismatic church, identified as Everitus, reportedly beat his wife, Fidelia, to death because of disagreement over money for Christmas food (Elekwa 2017). Similarly, Anenga (2017) relates the story of a church elder in Benue State who beat his wife to death. Until that incident, this church had upheld the traditional principle of 'for better, for worse'. According to Anenga (2017), before her death:

The woman who was also a church leader, would report her situation [of being beaten] to the church council, but the pastor and elders of the church would always encourage her to hang on, citing the scriptures and reminding her of her status as woman leader, and above all, the marriage doctrine of 'for better, for worse'. (n. p.)

When the murder occurred, Anenga narrates further, 'the pastor felt very guilty because unlike other mourners, he had a chance to save the woman but rather acted otherwise just to preserve the image of the church' (Anenga 2017:n.p.). With this incident, however, the church council revised its policy on divorce. Since then it has allowed for 'couples who are under persistent physical abuse ... to live separately (not divorce) in the interest of their life, and that of the children' (Anenga 2017:n.p.).

\section{The attitude of the church to intimate partner violence}

The case narrated above depicts the attitude of the church to women abuse in Nigeria. In view of the prohibition of divorce, in Nigeria, as in many other places, the counselling that abused women usually receive from the church is to endure it. As Grady (2001) puts it:

Significant numbers of Christian pastors ordinarily would tell a woman being abused that she should continue to submit and to trust that God would honor her action by either stopping the abuse or giving her the strength to endure it and would never advise a battered wife to leave her husband or separate because of abuse. (n. p.)

Similarly, Richards (1990:216) opines that no divorce is what many pastors counsel abused wives because they feel they have not the right to encourage them contrary to God's word. Pastors do not only advise abused women to endure but sometimes also put the blame on them. Oftentimes, a victim is accused of being beaten because she is not submissive, whereas (Maluleke \& Nadar 2002):

[T] he bible says she must be submissive; she is the one who needs to be counseled, marriage is like that ... They cite the bible that divorce is not permissible; anyone who tries to separate couples would face the wrath of God because what God has joined together, let no man put asunder. (pp. 7,9$)$

This submission is buttressed by Mate (2002) in her comparative study of the Zimbabwe Assemblies of God Africa (ZOAGA) and the Family of God churches' women's fellowship in Zimbabwe, in which 'she argues that the churches teach women to endure hardship in their marriages' (cited in Biri 2016:225). The encouragement to remain in abused marriages is often performed with the threat that divorcees will not make heaven, quoting scriptural passages held as forbidding divorce (Essien 2017). The suffering of victims is compounded when the encouragement to endure comes from women like themselves. Some Christian women leaders often encourage an abused woman to remain in her marriage, 'advising that she is not alone in her challenges because many others are undergoing the same' or even worse treatment (Biri 2016:235). Some women leaders describe men as naturally made to lead, dominate and rule, and must always be obeyed in all things, including their insatiable desire for sex (Guti 2006, cited in Biri 2016:226). In this way, the traditional African perception of the subservience of women is inherited by the church. For instance, among the Shona of Zimbabwe, a woman should not divorce but the husband may divorce her at his will - a perception inherited by ZOAGA (Biri 2016:228). This perception is also held in the traditional Yoruba (Nigerian) setting (Akinwumi 2012:249).

Another attitude of the church that can of discourage victims of domestic violence from liberating themselves is the treatment of divorcees. Ordinarily, in Africa, most women would want to remain in their marriages in spite of all odds in order 'to escape the social opprobrium of being labeled divorcees' (Biri 2016:228). Inadvertently exploiting this perception, some denominations treat divorcees with contempt and segregation, as 'they are sometimes not allowed to hold certain offices' in the church (Essien 2017). In this regard, Richards' (1990:237) submission is relevant for the Nigerian context. He affirms that in some denominations 'no divorced person can teach Sunday school or sing in choir. No divorced person can serve in a committee. And no divorced person can be remarried in the church'. It is noteworthy, as seen earlier, that these punitive attitudes are supported from the Bible; hence, Phiri (2002:25) is correct when she states that for partners in abusive relationships such passages 'become a death trap'.

On the whole, the attitude of the church in Nigeria to IPV is to endeavour to keep marriages intact even in situations where relationships have become life-threatening. The most the church seems to be willing to do, as seen in the story narrated by Anenga (2017) above, is to allow couples suffering violence to separate, but not to divorce. For instance, in the Catholic Church (Moore 2017):

In cases where living together has become too difficult or practically impossible, the Church permits a physical separation of the spouses ... but the two still remain married [because] their marriage bond ... [is] indissoluble. (n. p.)

In this way, the church adheres to the doctrine of prohibition of divorce and remarriage, principally supported with 1 Corinthians 7:10-11. Hence, in the following sections, we shall examine the social context of 1 Corinthians 7 , and the intent of 1 Corinthians 7:10-11 in relation to divorce and remarriage. 


\section{The socio-religious background of 1 Corinthians 7}

That the Apostle Paul was the author of First and Second Corinthians is rarely disputed among scholars (Carter \& Levine 2013; Winter 1994). As attested in 'Acts 18:1-7, Paul founded the church at Corinth after his visit to Athens', which is commonly dated around 50 CE (Winter 1994:1161, cited by Ademiluka 2017). Subsequently, Paul wrote to the congregation (Ac 1:1; 5:9), to which the Corinthians responded with visits from members of the church (1 Cor $1: 11 ; 5: 1 ; 7: 1 ; 16: 17-18$ ) (Carson et al. 1992:259; Carter \& Levine 2013:134). As evident in the report brought to him by 'some from Chloe's household' (1 Cor 1:11), after Paul left Corinth some controversies arose in the new church (Carson et al. 1992:259). We are really not sure of the nature of these controversies but from references such as 1 Corinthians 7:1, $8: 1,12: 1$ and $16: 1$, the major issues most likely concern 'factionalism and internal community relations, sexual ethics, and relations with people outside the church' (Carter \& Levine 2013:135).

The matter that Paul responds to in Chapter 7 seems to border on debates about celibacy, as the chapter opens with: 'Now concerning the matters about which you wrote, it is well for a man not to touch a woman' (7:1, RSV [Revised Standard Version]). The RSV, like some other versions, thus gives a literal translation of the Greek meaptesthai [not to touch], which connotes the idea of having sexual intercourse. Some versions (e.g. ESV [English Standard Version]) actually render it as 'not to have sexual relations with a woman'. However, the rendering 'not to marry' (as in NIV [New International Version] and Today's English Version [TEV]) is more appropriate in view of verse 2 , which advises everyone to marry 'because of the temptation to immorality'. The writer's intention is therefore better rendered 'It is good for a man not to marry' (NIV). Thus, the inquiry from the Corinthians to Paul most probably had to do with 'certain individuals who, out of religious motives, had voiced a wish for abstinence' from marriage (Baumert 1996:26). Apparently, having just been converted to Christianity, some Corinthians felt the urge for more devotion to the spiritual life, to which they saw marriage as a hindrance; hence, in 7:1, Paul responds to such persons' expression of their desire for celibacy (Baumert 1996:25). As can be reconstructed from 1 Corinthians 7, in the Corinthian church, all categories of members, married people (1 Cor 7:1-5, 10-16), single people (1 Cor 7:6-9) and engaged people (1 Cor 7:25-40) wanted answers to how to 'respond to the spiritual impulse towards abstinence' (p. 27). In 1 Corinthians 7, therefore, Paul was 'discussing marriages [and relationships] threatened by asceticism' (Abogunrin 2005:269).

There are indications in Paul's response that the desire for celibacy among members of the Corinthian church was also possibly being influenced by contemporary religious and philosophical thought on marriage. According to Keener (1993):
Divergent views on celibacy existed in the ancient world. Most ancient writers condemned it [while] many Jewish teachers even considered it sinful, because reproduction was essential and marriage was the proper deterrent from sexual offenses and distractions. [However, ] a number of groups of philosophers and minor religious sects as well as many Essenes among the Jews advocated celibacy or the rejection of marriage. [To them,] marriage is distraction and should never be undertaken by the wise man except in the rare instances where one might find a spouse equally devoted to the philosophic life. [To some others,] marriage is good for most people, but one must make exception for those too committed to other spiritual pursuits to take time for it. (p. 466)

Thus, in 1 Corinthians 7, Paul responds to converts who probably shared the view that marriage would not be compatible with their new spiritual lives. Hence, in this chapter, 'Paul is not dealing with abstractions, but with de facto conditions' (Okorie 2001:77). As Baumert (1996:27) rightly affirms, 'this is the key to the entire text. If on the other hand one ignores this Stizim Leben, and rather - which often occurs when the text is proclaimed in the liturgy - the statements are taken as general counsels for everyone, this can lead to serious misunderstandings'.

\section{Corinthians 7:10-11 in relation to divorce and remarriage}

In 1 Corinthians 7:10-11, Paul commands a wife not to 'separate' from her husband, and the husband not to 'divorce' his wife (RSV). Some other translations (e.g. New American Standard Bible [NASB]) use 'leave' instead of 'separate' and 'send away' in place of 'divorce'. The English versions may give the impression of a different form of command to husband and wife but the Greek verbs 'to separate' (chorizo, to depart, leave) and 'to divorce' (aphiemi, to let go, send away) 'were often synonyms for divorce and probably function as such in this text' (Keener 1993:467; cf. Adams 1980:34; Baumert 1996:53). That chorizo in this passage also means 'to divorce' is buttressed by the fact that Paul says that if the wife does indeed separate, she must remain unmarried (agamos):

Thus the separation he has in view in this passage is separation by divorce $\ldots$ because it was a separation that resulted in an agamos or unmarried state. Paul was [therefore] thinking of the finalized result of the divorce process. (Adams 1980:34)

Moreover, interpreters are unanimous that the idea of an enduring, definitive "separation" while the marriage itself continues nominally was ... unknown in Jewish and Christian circles' (Baumert 1990:53; cf. Adams 1980:34).

Hence, the situation Paul responds to in this text is most probably one in which the desire for celibacy threatens an established marriage. Apparently, because of 'religious rigorism ... one partner wishes to really dissolve the marriage so as to be able to live celibately ...' (Baumert 1996:52, 53). Many are in agreement that at the background lay some religious exuberance in which an ascetic view possibly 
'saw conjugal activity as a hindrance to one's spiritual life' (Okorie 2001:70). There are suggestions that Paul is referring to a situation where the protester (most probably the wife) had already deserted the husband, or was about to leave when his visitors from Corinth came with the news. To this end, Paul 'writes presuming that the divorce is a fait accompli' (p. 70). It may be for this reason that Paul has to strengthen his directive with Jesus' command on divorce, thereby insisting that the wife must not separate from her husband, but if she has indeed left, she must remain unmarried or 'reconcile with her former husband' (p. 70). Thus, when taken at its face value, this passage forbids divorce as already commanded by Jesus. If divorce does take place, the initiator must remain unmarried or be reconciled to his or her spouse, which implies that remarriage is also being forbidden. Perhaps, it is this literal view that led to the traditional interpretation of 1 Corinthians 7:10-11 (often supported with v. 39) of an outright prohibition of divorce.

However, before we can correctly interpret Paul's position in this passage, we have to understand the command of Jesus which he alludes to. It is hardly disputed that Paul's allusion is to Jesus' teaching on divorce as contained in the gospels (Mk 10:2-12; Mt 5:31-32; 19:3-12; Lk 16:18). In the Markan and Matthean accounts, the Pharisees query Jesus if it is lawful to divorce one's wife for any reason. Rather than answering the question directly, Jesus refers them to Genesis 2:24 which states that originally, God did not intend couples to be separated, but husband and wife to become one flesh. Therefore, 'what God has joined together, let not man put asunder' (Mt 19:6, RSV). Apparently not getting the answer they wanted, the Pharisees query further why Moses allowed them to divorce a woman by simply giving her a certificate of divorce, thereby referring to Deuteronomy 24:1-4. According to the account in Mark, Jesus replies that Moses did it because of the Hebrew man's hardness of heart, adding that 'Whoever divorces his wife and marries another, commits adultery against her; and if she divorces her husband and marries another, she commits adultery' (Mk 10:11-12, RSV). But the corresponding portion in Matthew includes the so-called exception clause, '... whoever divorces his wife, except for unchastity, and marries another, commits adultery' (Mt 19:9; cf. 5:32, RSV).

There are varied suggestions why the exception clause appears in Matthew but not in the other gospels. Some regard Mark 10:2-12 as Jesus' real statement on divorce and the exception clause as a later addition by Matthew. For example, in the opinion of Heth (1990:95), the exception clause 'is not part of genuine teaching of Jesus'. But Edgar (1990:168) argues that the exception in Matthew 'must be understood as an omission of a detail by Mark' and Luke, rather than an addition by Matthew. Some also reason that the disciples' reaction to Jesus' statement ('If such is the case of a man with his wife, it is not expedient to marry' [Mt 19:10]) is too strong to have been a response to the so-called exception; so Jesus did not state any exception (Edgar 1990:168). However, as we shall see presently, it is possible that the Jewish society of the disciples' day was one which supported divorce for any reason. In that case, Jesus' allowance for divorce only on grounds of sexual immorality was a hard one, which would explain the disciples' reaction (Edgar 1990:171). Keener (1993:161) seems to support the fact that Jesus' position on divorce was relatively hard when he opines that Jesus' statement that any man who divorces his wife and marries someone else commits adultery 'is hyperbolic, that is, it has exaggerated intensified force. No one else in antiquity spoke of divorce in such strong terms'. Some who view Matthew's exception as a later addition suggest it is an attempt by him to soften a total prohibition of divorce by Jesus which soon proved unworkable in real life (France 1994:929). Against this view, France (1994:929) opines that Matthew might simply be 'spelling out what any Jewish reader would have taken for granted, that marital unfaithfulness automatically annulled a marriage'. To buttress this point, he refers to Joseph's dilemma when he found Mary to be pregnant (Mt 1:18-19), whereas they had not met sexually, which implies that she must have committed adultery. In the Old Testament, the penalty for this act was death, but by the time of Joseph, a formal annulment of the engagement or marriage was the normal response. Another view regards Matthew's exception clause as 'an exegetical addition which he attributed to Jesus' divorce sayings ... in an attempt to apply it to the situation of his audience' (Omowole 2006:131). In that case, Matthew reinterpreted Jesus' words, indicating that the corresponding sayings in the other gospels are a general statement by which Jesus did not intend to establish a new law on divorce.

To properly place the Matthean exception, it is necessary to study the law of Moses which the Pharisees refer to in their encounter with Jesus. The Old Testament law which talks about divorce by certificate is Deuteronomy 24:1-4, which states that if a man finds 'some indecency' (v. 1, RSV, NAU [New American Standard Bible]) in his wife, he may write her a bill of divorce and send her away. The divorced wife may marry another man but the first husband is not allowed to marry her again. In the opinion of Laney (1990:24), the purpose of this legislation 'was to discourage divorce among the Israelite people; since there was a good possibility of not being able to remarry one's former wife, the husband would not be so likely to put his wife away so hastily'. While it is not impossible for this law to discourage divorce for the reason stated by Laney, it is very clear that the Mosaic law indicates the regulations governing divorce some time in ancient Israel. As Edgar (1990:154) rightly points out, this law shows that a man might divorce his wife for indecency, and both the man and the divorced wife are free to marry anyone else. The reason for which a man may divorce his wife according to this law is termed in the King James Version (KJV) as some uncleanness. Other translations such as the RSV, NAU and NIV give the cause as some indecency. The Hebrew word they all attempt to translate is erwah [nakedness]. In the Old Testament, nakedness is often not tolerated outside proper sexual relationships, and when it occurs, the persons involved are accused of adultery (Allen 1980:695). For example, in Leviticus 18 and 20 to 'uncover nakedness' 
is used for sexual relationship between relatives, and is considered as adultery (Lv18:20; 20:10). Hence, the indecency in Deuteronomy 24:1 is better understood as adultery; in other words, in ancient Israel, a man might divorce and remarry for the reason of adultery.

Jesus' contemporary Jewish society must have understood this law in this sense. In the passage under discussion, the Pharisees ask Jesus the question on divorce 'in order to test him' (Mk 10:2; cf. Mt 19:3), which means that the Pharisees wanted to drag Jesus into the rabbinic debate on divorce (Keener 1993:96), possibly to know which of the views he supported. In Jesus' day, there were two schools of thought on the issue of divorce. The school of Shamai, said to be predominant at that time, argued that Deuteronomy 24:1-4 allowed divorce on account of adultery; it also did not consider remarriage after divorce as adulterous. The school of Hillel, on the other hand, said that a man could divorce his wife for any reason (Adams 1980:51; Edgar 1990:171; Keener 1993:96). Thus, Jewish traditions at the time of Jesus allowed a man, on grounds of adultery on the part of the wife, to divorce her and marry another. Therefore, as there are no indications that Jesus intended to establish a new law on divorce, his saying in Mark and Luke should be understood as a general statement in which the exception in Matthew is implied. Perhaps this is the perspective in which Matthew understood Jesus' statement, hence his inclusion of the exception. Edgar (1990:154) summarises this point succinctly, saying 'Mark 10:2-12 describes the same statement by Jesus as that quoted in Matthew 19:9; therefore, the additional details in Matthew 19:3-12 must be understood in Mark 10:2-12'.

Nevertheless, some argue that what the exception allows is not divorce but annulment of incestuous marriage, implying that porneia refers to an invalid marriage, specifically a marital union between blood relations. In that case, such a marriage is contrary to the prohibited relationships in Leviticus 18 and 20, and therefore an invalid marriage. The exception is thus 'not really an exception since it does not actually concern divorce but an annulment' (Edgar 1990:178). Laney (1990) is one of those who hold the incestuous marriage view. According to him:

In Matthew 19:9 Jesus is teaching 'no divorce', save the exceptional situation where marriage has taken place within the prohibited relationship of Leviticus 18:6-18. There is no question that Matthew addressed his gospel to a Jewish audience ... [for whom] ... the matter of porneia would be a problem of primary concern. This would account for the inclusion of the exception clause in Matthew, and its absence in Mark and Luke, which are addressed to Roman and Greek readers respectively. If porneia were to be interpreted broadly, there is no reason for Mark to have omitted the exception from Jesus' teaching on divorce. (p. 36)

Implicitly, this view is saying that Jesus gave the exception clause but in reference to incestuous marriage prohibited in Leviticus 18. Matthew included it because a ban on divorce would make meaning to his Jewish audience only in the context of the prohibition of incestuous marriage in Leviticus. Mark and Luke did not include the exception clause because it would have no relevance for their respective readers. However, this interpretation would further imply that the individual reports of the evangelists on the sayings of Jesus were determined by the intended audience irrespective of the original words of the speaker. But this view would have a repudiating effect on the gospels as we can no longer be sure of the actual teachings of Jesus. It appears more logical, as discussed earlier, to regard the accounts in Mark and Luke as the general statement of Jesus on divorce, in which the exception in Matthew is implied.

However, the issue at stake has to do with the word porneia as used in Matthew 5:32 and 19:9. Adams (1980:54) says porneia refers to sexual sin of all sorts, while according to Edgar (1990:162), the Greek porneia 'has the meaning of "illicit sex", and can refer to illicit sex in general or, in a given context, to some specific immorality'. Richards (1990) also affirms that in later Jewish rabbinic language, the word zenut (porneia) included:

Not only prostitution and any kind of extra-marital sexual intercourse but also all marriages between relatives forbidden by rabbinic law; incest and all kinds of unnatural sexual intercourse were viewed as fornication (porneia). (p. 230)

That porneia is capable of omnibus use is further expressed by Adams (1980:54) when he says that in the Bible, apart from sexual sin in general, porneia is also used to describe cases of incest (1 Cor 5:1), homosexuality (Jud 7) and even adultery (Jr 3:1, 2, 6, 8). ${ }^{1}$

Porneia then refers to any act of sexual intercourse outside proper marriage. While incestuous marriage as prohibited in Leviticus may conform to the term porneia, 'there is insufficient evidence to establish that porneia was ever used to refer to an incestuous marriage' (Edgar 1990:181). There is also no evidence that the reference in the exception clause is to incestuous marriage. Rather, in the passage under discussion, the Pharisees make reference to a specific law of Moses that commands one to give a bill of divorce (Mt 19:7), which is a clear reference to Deuteronomy 24:1-4, as mentioned earlier. As Edgar (1990:178) plausibly states, 'If the exception is the case of incestuous marriage, it is odd that there is no reference to the Old Testament passage which describes the alleged exception'. No doubt, Matthew's audience would have understood porneia in its general meaning of illicit sex outside proper marriage.

So far we have discovered that as the Jewish society of Jesus' day had the custom of divorce and remarriage, the exception clause in Matthew is implicit in Mark and Luke. Therefore, there is no reason to doubt that the exception is also implied in 1 Corinthians 7:10-11. Edgar (1990:188) buttresses this fact when he says that in 1 Corinthians 7:10-11:

1.According to Adams, porneia and moichao [adultery] occur jointly in Sirach $22: 22$ 23 where an unfaithful wife 'has committed adultery by fornication', which means 23 where an unfaithful wife 'has committed adultery by fornication', which means
that by engaging in sexual sin, she violated her covenant commitment to her husband (Adams 1980:54). 
Paul definitely states that the position on divorce and remarriage was given by Jesus ... [T] he exception must be understood in 1 Corinthians 7:10-11, just as it must be understood in Mark 10:2-12. (Edgar 1990, 188)

Paul does not have to state the exception here because it is irrelevant in the context of the discussion, namely one in which one partner has made up her mind to divorce in order to practice celibacy. Hence, this text does not negate the fact that a Christian spouse may divorce and remarry because of fornication on the part of the other.

As a matter of fact, rather than forbid divorce and remarriage, it can be deduced from 1 Corinthians 7:10-11 that Paul would support divorce and remarriage even for reasons other than sexual immorality. In the first place, the statement that if the woman divorces she should remain unmarried, or be reconciled to her husband (v. 11) 'necessarily applies to one who divorced for reasons other than the exception, otherwise, as it is clear from Matthew 19:9, they are allowed to [re] marry' (Edgar 1990:189). In other words, the matter would not have come up at all if the reason for which the woman wanted to leave concerned porneia. Furthermore, Paul does not state what is expected of the deserted spouse in an event that she leaves indefinitely. Should he remain unmarried or is he allowed to remarry? Paul does not answer this question here but his statements in respect of mixed marriages in verses $12-16$ are instructive. In verse 15 , Paul says that if the unbeliever wants to divorce, the believer is oudedoulotai ('not bound' [or] 'not enslaved'). There are those who assert that oudedoulotai does not permit the deserted believer to remarry. In the opinion of Laney (1990:43), for example, the text does not support remarriage for several reasons. Firstly, Paul is not likely to permit in verse 15 what is forbidden in 10-13, as according to Paul, there is no difference between a marriage between Christians and a mixed marriage. Secondly, Paul recognises the possibility of unapproved divorce among Christians, but in Jesus' command remarriage to another person was not allowed (vv. 10-11). Thus, going by his second reason, Laney does not accept that the exception clause in Matthew is implied in the command of Jesus which Paul refers to in 1 Corinthians 7:10-11. He therefore concludes that 'not bound' in 1 Corinthians 7:15 only means that the Christian partner may permit the divorcing partner to leave but the former is not permitted to marry another person. Similarly, Baumert (1996:61) states that in verse 15, the Christian is being instructed to 'go along with the separation and give their consent without having bad conscience'. For Baumert, 'not bound' means that the Corinthians should not see Paul's counsel as an enslaving law but feel free to use it according to their own discretion.

Nevertheless, it seems that there is overwhelming evidence that 1 Corinthians 7:15 permits remarriage. Contrary to the view that 'not bound' can only mean 'not bound to stay with' as implied by Laney and Baumert, Keener (1993:467) explains that the phrase 'not bound' 'alludes to the wording of Jewish divorce documents which told the woman "You are free to marry any man."' In that case, it is correct to say that 'not bound' in verse 15 means that, 'all the bonds of marriage are removed; [the deserted believer] is released entirely from every marriage obligation, and is a totally free person' (Adams 1980:48). As Richards (1990:239) puts it, in this place, 'Paul says that the abandoned spouse is "not bound" by the marriage vow, implying that he/she is now "unmarried" and thus free to marry'. Moreover, the idea that 'not bound' means only 'not bound to stay with' is illogical because 'If the unbeliever leaves, the believer can hardly have any choice in the matter' (Edgar 1990:190); in other words, the Christian cannot prevent the divorce. The abandoned partner is now divorced, unmarried and not bound (i.e. free), a situation in which many believe Paul cannot but mean that the deserted partner is free to remarry. Edgar is therefore right when he concludes on this verse that 'it is most probable that Paul allows not only divorce but subsequent remarriage in the case of desertion by an unbeliever' (Edgar 1990:190).

This implies that the believer who is deserted by an unbeliever in 1 Corinthians 7:12-16 and the one abandoned by a fellow Christian in verses 10-11 have something in common, namely they are both agamos. If the one divorced by a non-Christian is free to remarry, there is no reason why the one deserted by a fellow Christian is not free to remarry. Therefore, 1 Corinthians 7:10-11 does not only allow a Christian to divorce on grounds of adultery but also permits a Christian deserted by his or her partner to remarry. As expressed by Edgar (1990):

Although it is not definitely stated that desertion by a believer likewise allows for divorce and remarriage for the deserted spouse, according to 1 Corinthians 7:10-14, there is no substantial difference between the validity of a mixed marriage and the marriage of two believers. ... Therefore, although not specifically stated, desertion even by a believer may be grounds for divorce and remarriage. (p. 191)

However, some interpret 1 Corinthians 7:39, which states that a 'wife' is bound to her husband until he dies, to support the argument against divorce and remarriage. For example, consistent with his view that verse 15 does not allow remarriage, Laney (1990:44) maintains that in verse 39, Paul describes the marriage commitment as 'binding until death'. But if one is aware that the Greek word gune is used for both 'woman' and 'wife', one is able to read verse 39 as continuing from verse 25 where the discussion on the betrothed begins. In that case, gune in verse 39 refers to an engaged woman, and not to the married. This point is clear from verse 27 where gune definitely refers to 'woman' in a betrothed status. Verse 27 already indicates that the engagement is legally binding; hence, in verse 39, Paul means that the engaged woman is free either to consummate the marriage or remain in a celibate relationship with her fiancé. 'Paul is of the opinion that this form of celibacy is only obligatory for the fiancée as long as this man lives. For a widow this would be clear; for an engaged woman, however, who had chosen the path of celibacy, this remained a real question' (Baumert 1996:128). This means that verse 39 is not relevant for the 
issue of divorce and remarriage of married persons. Hence, Keener (1993) is right to state that:

those who hold that this verse excludes remarriage of divorced persons ignore not only 7:15, 27-28, but also the language of antiquity [by which] no one considered her former spouse as 'her husband' after a legitimate divorce had taken place. (p. 469)

Thus, when 1 Corinthians 7:10-11 is properly understood in its specific original social context, it does not prohibit divorce and remarriage. The traditional approach which led to the creed of marriage 'for better, for worse, until death do us part' must have arisen from the erroneous generalisation of the text for all times and all marriages. Hence, in the following section, we shall examine how our new understanding of 1 Corinthians 7:10-11 should impact on the attitude of the Church and Christians towards divorce and remarriage in the context of IPV in Nigeria.

\section{Implications for the intimate partner violence context in Nigeria}

As seen earlier, conditioned by the traditional interpretation of 1 Corinthians 7:10-11 of prohibition of divorce and remarriage, abused spouses have always been encouraged to remain in their marriages in order not to contravene the word of God. The highest point the church could reach is to advise spouses to live separately, but sometimes this is performed only when lives have been lost to domestic violence. However, from our examination of the text in its specific context, we have discovered that 1 Corinthians 7:1011 permits a Christian to divorce and remarry on grounds of sexual immorality, and a deserted spouse to remarry. In Nigeria, sexual immorality, especially on the part of the husband, is frequently a form of IPV. ${ }^{2}$ Usually, the man starts by entering into an extra-marital love affair; he begins to come home late or spending some nights out of the matrimonial home. In this way, he is combining the activity with desertion, which often comes along with the denial of conjugal and economic rights of his partner. This happens when the man begins to spend his resources on the newfound love. The wife and the children become destitute if he is the sole breadwinner of the family. It is important to note, however, that sometimes a man's extra-marital affair is caused by his wife's behaviour. Attitudes of a woman that often lead to this include disobedience, non-submission, nagging, denial of conjugal rights and laziness in performing her house duties, among others. These traits may induce the husband to begin to avoid his home, seeking peace elsewhere. Moreover, some married women also indulge in extra-marital affairs. Sometimes, a woman falls into it if the temptation comes from a man who is wealthier than her husband. There are many cases of women who have left their husbands for richer men; more often than not, before they left, they had an illicit love affair with the new man. In view of the new interpretation of 1 Corinthians 7:10-11, in cases like these, the

\footnotetext{
2.We have to state right away that with the stories of domestic violence perpetrated by Christian leaders and pastors as related in the section on IPV in Nigeria, it becomes clear that the religion has very little control over people's character, becomes clear that the religion has very little control over people's character,
especially when the issues relate to marriage. Hence, the discussion below pertains to men and women who profess the Christian religion.
}

innocent party is free to divorce and remarry. Abandonment or desertion of wife is a frequently occurring form of domestic violence towards women today (Kunhiyop 2008:244). It takes several forms but generally involves 'men going away from home and leaving the children and mother without any support' (Nwakwo 2008:4; Osisiogu 2016:380). Stories abound in Nigeria of men who, after marriage in Nigeria, find their way out of the country and break contact with their wives completely. In this type of situation, the woman suffers psychological trauma in addition to the effects of desertion mentioned above. As mentioned above, our interpretation of 1 Corinthians 7:10-11 permits the deserted Christian to remarry.

It is noteworthy, however, that in the context of IPV in Nigeria, there are marital problems that are worse than adultery and desertion. As seen in the section on IPV, there are conditions which do not only amount to threat to life but do actually take lives. In cases where domestic violence takes the form of threat to life, 1 Corinthians 7:10-11 does not tell us what to do, but deductions can be made from the chapter. According to Jewish custom, the only reason for which one could divorce and remarry is sexual immorality, but in verse 11 , Paul is faced with the case of a spouse ready to divorce her partner in order to practice celibacy. This is a new situation and therefore demands a new response, namely the woman must remain unmarried or return to her husband. Similarly, concerning mixed marriages (vv. 12-16) and engaged persons (vv. 25-40), Paul says he has no command of the Lord; that is, again, he meets situations on which he has no leading of scripture, and has to allow the reality of the new situation to determine the response. In the case of a mixed marriage, for example, he sees no reason for the Christian to divorce his non-Christian spouse, but if the non-Christian decides to leave, the Christian is at liberty to marry another person. Thus, in cases such as constant wife battery, acid bath and other forms that constitute threat to life, where the church and the affected Christians do not have the leading of scripture, they should allow the reality of the situation to determine the appropriate response. When there is threat to life, one would think that the appropriate response from the church should be to dispense with marriage in order to save life; that is, divorce should be recommended.

\section{Conclusion and recommendation}

The menace of IPV has been on the increase in Nigeria as in many parts of the world. Christians who suffer IPV remain in their marriages for several reasons but perhaps the strongest of such reasons is the doctrine that the Bible forbids divorce. One of the passages quoted in support of this teaching is 1 Corinthians 7:10-11. Hence, this work examined this text in its original social context as it relates to divorce and remarriage. The research found that when understood in its specific context, 1 Corinthians 7:10-11 permits divorce and remarriage because of sexual immorality, and allows a spouse deserted by another to remarry. Therefore, wherever IPV takes these forms, the innocent party is allowed to divorce and remarry. For other forms of domestic violence, it can be 
deduced from the text that the church and the affected Christians should allow the specific situation to determine the appropriate response. For example, when IPV poses threat to life, divorce should be advised, and the spouses are allowed to remarry if they so desire. However, Christians must understand that in 1 Corinthians 7, Paul's ultimate aim is to protect marriage as a permanent institution; hence, wherever this ideal cannot be achieved and divorce has to take place, 'we ... [should] still remain open to and even seek reconciliation' (Richards 1990:242).

\section{Acknowledgements Competing interests}

The author declares that he has no financial or personal relationships that may have inappropriately influenced him in writing this article.

\section{Authors' contributions}

S.O.A. is the sole author of this article.

\section{Funding information}

This research received no specific grant from any funding agency in the public, commercial or not-for-profit sectors.

\section{Data availability statement}

Data sharing is not applicable to this article as no new data were created or analysed in this study.

\section{Disclaimer}

The views and opinions expressed in this article are those of the author and do not necessarily reflect the official policy or position of any affiliated agency of the author.

\section{References}

Abogunrin, S.O., 2003, 'Biblical studies and the gender problem', in S.O. Abogunrin (ed.), Biblical studies and women issues in Africa, pp. 1-13, Nigerian Association for Biblical Studies, Ibadan.

Abogunrin, S.O., 2005, 'Decolonizing New Testament interpretation in Africa', in S.O. Abogunrin (ed.), Decolonization of biblical interpretation in Africa, pp. 249-279, Nigerian Association for Biblical Studies, Ibadan.

Adamolekun, T., 2006, 'Marriage and divorce from Christian perspective: An examination of Pauline corpus', in S.O. Abogunrin (ed.), Biblical view of sex and sexuality from African perspective, pp. 138-150, Nigerian Association for Biblical Studies, Ibadan.

Adams, J.E., 1980, Marriage, divorce and remarriage in the bible, Presbyterian \& Reformed, Philipsburg.

Ademiluka, S.O., 2017, ' 1 Corinthians 14:33b-36 in light of women and church leadership in Nigeria', Verbum et Ecclesia 38(1), viewed 22 January 2018, from https://tinyurl.com/ya8mh8r7.

Adesanya, B., 2009, 'Marriage, divorce and succession: The legal aspects', paper presented at a seminar marking the 10th anniversary of the Diocese of Lagos West (Anglican Communion) at the Archbishop Veining Memorial Church Cathedral on the 12th of June 2009.

Agene, M., 2017, 'The reality of domestic violence in Nigeria', Women for women viewed 13 July 2018, from https://www.womenforwomen.org/blog/realitydomestic-violence-nigeria.

Agbonkhese, J. \& Onuoha, C., 2017, 'Does Nigerian culture permit domestic violence?', Vanguard, 24 August, viewed 12 December 2017, from https://www.vanguardngr com/2017/08/nigerian-culture-permit-domestic-violence/.

Akinwumi, S.O., 2012, 'Evolving a viable feminist biblical hermeneutic theory towards the improvement of women's status in Africa', in D.D. Adegbite et al. (eds.) Biblical studies and feminism in the African context, pp. 248-262, Nigerian Association for Biblical Studies (Western Zone), Ibadan.
Allen, R.B., 1980, 'Erwa', in R. Laird Harris et al. (eds.), Theological wordbook of the Old Testament, p. 695, Moody Publisher, Chicago, IL.

Anenga, U., 2017, 'The role of the church in marriage', The Guardian, 26 November, viewed 13 July 2018, from https://guardian.ng/opinion/role-of-the-church-inmarriage/.

Antai, D., 2011, 'Controlling behavior, power relations within intimate relationships and intimate partner physical and sexual violence against women in Nigeria', BioMed Central Public Health 11(2011), 1-11. https://doi.org/10.1186/14712458-11-511

Babajide-Alabi, M., 2017, 'Let's talk about rape', Vanguard, 17 September, viewed 01 December 2017, from https://www.vanguardngr.com/2017/09/lets-talk-rape/.

Baffour, K., 2014, 'Rape in Nigeria: Sexual predators on the prowl', NAlJ.com, viewed 05 December 2017, from https://www.naija.ng/62529.html.

Baloyi, E.M., 2010a, 'A re-reading of John 8:1-11 from a pastoral liberative perspective on South African women', HTS Teologiese Studies/Theological Studies 66(2), Art. \#838, 1-7 pages. https://doi.org/10.4102/hts.v66i2.838

Baloyi, E., 2010b, 'An African view of women as sexual objects as a concern for gender equality: A critical study', Verbum et Ecclesia 31(1), Art. \#380, 1-6. https://doi. org/10.4102/ve.v31i1.380

Baloyi, M.E., 2013, 'Wife beating amongst Africans as a challenge to pastoral care', In die Skriflig/In Luce Verbi 47(1), Art. \#713, 1-10. https://doi.org/10.4102/ids. v47i1.713

Baumert, N.S.J., 1996, Woman and man in Paul: Overcoming a misunderstanding, transl. P. Madigan, \& L.M. Maloney, Michael Glazier, Collegeville, MN.

Biri, K., 2016, 'Proverbs 31 woman: Pentecostalism and "disempowering femininities" and "oppressive masculinities" in Zimbabwe: A critique', in J. Kugler, L. Tagarasei \& M.R. Gunda (eds.), The Bible and violence in Africa: Bible in Africa Studies, vol. 20, pp. 223-238, University Press, Bamberg.

Canada: Immigration and Refugee Board of Canada, 2012, Divorce law and practices among Christians, viewed 13 July 2018, from http://www.refworld.org/docid/ 50aa3f7a2.html

Carson, D.A., Douglas, J., Moo, D.J. \& Morris, L., 1992, An introduction to the New Testament, Zondervan, Grand Rapids, MI.

Carter, W. \& Levine, A.J., 2013, The New Testament: Methods and meanings, Abingdon Press, Nashville, TN.

Centers for Disease Control and Prevention, 2014, Intimate partner violence prevention: Definitions, viewed 02 December 2017, from https://tinyurl.com/ y7p7akhd.

Christian Media in Nigeria, 2015, Rate of divorce among Christian couples alarming viewed 13 July 2018, from http://www.christianmediang.com/2015/10/rate-ofdivorce-among-christian-couples.html.

'Cleric laments rising cases of divorce in churches', 2018, The Guardian, 14 May, viewed 13 July 2018, from https://guardian.ng/news/cleric-laments-rising-casesof-divorce-in-churches/.

Delano, L., 1998, 'Sexual abuse and violence in Sub-Saharan Africa', Advocates for Youth, viewed 01 November 2017, from https://advocatesforyouth.org/ resources/sexual-abuse-and-violence-in-sub-saharan-africa.

Edgar, T.R., 1990, 'Divorce and remarriage for adultery or desertion', in W.H. House (ed.), Divorce and remarriage: Four Christian views, pp. 151-196, Intervarsity Press, Downers Grove, IL.

Egbujo, U., 2015, 'Nigeria: A nation of wife-beaters?' Vanguard, 02 May, viewed 14 July 2018, from https://www.vanguardngr.com/2015/05/nigeria-a-nation-ofwife-beaters/.

Elekwa, E., 2017, 'Nigeria: Ex-boxer on the run for beating wife to death over Xmas food', Daily Trust, 29 December, viewed 14 July 2018, from https://allafrica.com/ stories/201712290459.html.

Essien, C., 2017, 'Solutions to domestic violence in Nigeria', Opinion Nigeria, viewed 13 July 2018, from http://www.opinionnigeria.com/solutions-to-domesticviolence-in-nigeria-by-barr-christiana-essien/\#sthash.z2uSVvOT.dpbs.

Folayan, M.O., Odetoyinbo, M., Harrison, A. \& Brown, B., 2014, 'Rape in Nigeria: A silent epidemic among adolescents with implications for HIV infection', Global Health Action 7(2014), viewed 15 January 2017, from https://www.ncbi.nlm.nih. gov/pmc/articles/PMC4142225/.

Fowowe, P., 2015, 'My Pastor beats his wife ... how can I help?' The Cable, 03 August, viewed 15 July 2018, from https://www.thecable.ng/pastor-beats-wife-canhelp.

France, R.T., 1994, 'Matthew', in D.A. Carson, G.J. Wenham, J.A. Motyer \& R.T. France (eds.), New Bible commentary, pp. 904-945, IVP, Nottingham , IL.

Grady, J.L., 2001, 'Control freaks, and the women who love them', New Man, January/ February, viewed 13 July 2018, from https://en.wikipedia.org/wiki/Christianity and_domestic_violence.

Guti, E., 2016, Wise woman, EGEA, Harare.

Hart, B., 2016, 'Shame of Nigeria - Statistics of violence against women', NAIJ.com, viewed 05 January 2018, from https://www.naija.ng/430683-every-fourth-nigerianwoman-suffers-domestic-violence.html\#430683.

Keener, C.S., 1993, The IVP Bible background commentary: New Testament, IVP, Nottingham, IL.

Hasstedt, K. \& Rowan, A., 2016, 'Understanding intimate partner violence as a sexua and reproductive health and rights issue in the United States', GPR 19, 37-45, viewed 02 December 2017, from https://tinyurl.com/ybup2fpn.

Kunhiyop, S.W., 2008, African Christian ethics, WordAlive, Nairobi. 
Heth, W.A., 1990, 'Divorce, but no remarriage', in W.H. House (ed.), Divorce and remarriage: Four Christian views, pp. 73-129, Intervarsity Press, Downers Grove, IL.

Igbelina-Igbokwe, N., 2013, 'Contextualizing gender based violence within patriarchy in Nigeria', Pambzuka News: Voices for Freedom and Justice (2013), 1-12, viewed 28 January 2018, from https://tinyurl.com/ycmmoy2g.

Johnson, D., 2018, 'Churches asked to check divorce rates', Vanguard, 04 February, viewed 13 July 2018, from https://www.vanguardngr.com/2018/02/churchesasked-check-divorce-rates-2/.

Kirk-Dugan, C., 2012, 'Precious memories: Rule of law in Deuteronomy as catalyst fo domestic violence', in A. Brenner \& G.A. Yee (eds.), Exodus and Deuteronomy, pp. 258-288, Fortress, Minneapolis, MN.

Laney, C.J., 1990, 'No divorce and no remarriage', in W.H. House (ed.), Divorce and remarriage: Four Christian views, pp. 15-54, Intervarsity Press, Downers Grove, IL.

Maluleke, T.S. \& Nadar, S., 2002, 'Breaking the covenant of violence against women', Journal of Theology for Southern Africa 114, 5-17.

Mate, R., 2002, 'Wombs as God's laboratories: Pentecostal discourses of feminity in Zimbabwe', Africa 72, 549-560. https://doi.org/10.2307/3556701

Moore, T., 2017, 'Why it's hard to get a divorce in Catholic Church', City People, 11 May, viewed 13 July 2018, from http://www.citypeopleonline.com/hard-getdivorce-catholic-church/.

Nwakwo, O., 2008, 'Effectiveness of legislation enacted to address violence against women in Nigeria', paper presented at expert group meeting on good practices in legislation on violence against women, United Nations Office, Vienna, Austria, 26th-28th May 2008, pp. 1-49.

Okenwa, L., Lawoko, S. \& Jansson, B., 2009, 'Factors associated with disclosure of intimate partner violence among women in Lagos, Nigeria', Injury and Violence 1(1), 37-47. https://doi.org/10.5249/jivr.v1i1.15

Okorie, A.M., 2001, 'Divorce and remarriage: An exegetical analysis of 1 Corinthians 7:10-16', African Journal of Biblical Studies XVI(I), 68-81.
Okorie, A.M., 2003, 'Biblical studies and women issues: Marriage', in S.O. Abogunrin (ed.), Biblical studies and women issues in Africa, pp. 68-81, Nigerian Association for Biblical Studies, Ibadan.

Omowole, S.O., 2006, 'Marriage and divorce: The New Testament view', in S.O. Abogunrin (ed.), Biblical view of sex and sexuality from African perspective, pp. 126-137, Nigerian Association for Biblical Studies, Ibadan.

Ose, A.N., 2009, 'Prevalence of domestic violence in Nigeria: Implications for counseling', Edo Journal of Counselling 2(1), viewed 02 January 2018, from https://www.ajol.info/index.php/ejc/article/download/52648/41252.

Osisiogu, U., 2016, 'Physical abuse of women in the home: A Nigerian perspective', Humanities and Social Sciences Review 5(3), 379-394.

Partab, R., 2011, 'Why do violent men do what they do?: Dialoguing on privileges of patriarchy and domestic violence', Journal of Gender and Religion in Africa 17(1), 96-113.

Phiri, I.A., 2002, 'Why does God allow our husbands to hurt us? Overcoming violence against women', Journal of Theology for Southern Africa 114, 9-30.

Richards, L., 1990, 'Divorce and remarriage under a variety of circumstances', in W.H. House (ed.), Divorce and remarriage: Four Christian views, pp. 215-248, Intervarsity Press, Downers Grove, IL.

The Redeemed Christian Church of God, 2010, Solemnization between Oluwatobilola Adeola and Ayodeji Paul, RCCG, Sagamu, Nigeria.

United Missionary Church of Africa, 2013, Solemnization between Saint Malik and Kehinde Goodness Hope, UMCA, Lokoja, Nigeria.

Winter, B., 1994, '1 Corinthians', in D.A. Carson et al. (eds.), New Bible commentary, pp. 1161-1187, IVP, Nottingham.

Woman.NG, 2017, 20 Women share their stories of sexual abuse in church, viewed 15 July 2018, from http://woman.ng/2017/12/20-women-share-their-stories-ofsexual-abuse-in-church/. 